\title{
Toxoplasmosis and tuberculosis: brain lesions in HIV/ AIDS differentiated by response to therapy
}

\author{
Megha Priyadarshi, Umang Arora 두 , Pankaj Jorwal
}

Medicine, All India Institute of Medical Sciences, New Delhi, Delhi, India

\section{Correspondence to} Dr Pankaj Jorwal; pankajjorwal.aiims@gmail.com

Accepted 14 May 2021

\section{Check for updates}

(C) BMJ Publishing Group Limited 2021. No commercial re-use. See rights and permissions. Published by BMJ.

\footnotetext{
To cite: Priyadarshi $M$, Arora U, Jorwal P. BMJ Case Rep 2021;14:e243470. doi:10.1136/bcr-2021243470
}

\section{DESCRIPTION}

A 54-year-old man presented with a 1-month history of generalised weakness and a 2-day history of altered sensorium with poor response to verbal commands and repetitive speech, along with headache and vomiting. Neurological examination did not reveal any focal motor, sensory, or cerebellar abnormalities or meningismus. He was diagnosed with AIDS due to the HIV serotype 1 twelve years prior to the presentation but was not compliant to antiretroviral therapy (ART). He was found to have a low CD4 count of 52 cells $/ \mathrm{mm}^{3}$, and a viral load of 50000 copies $/ \mathrm{mL}$.

With a suspicion of opportunistic infection afflicting the central nervous system (CNS), he was evaluated; and lumbar puncture revealed normal cerebrospinal fluid (CSF) pressure $(12 \mathrm{~cm}$ water), elevated leucocyte count (10 cells, all lymphocytes), protein $(132 \mathrm{mg} / \mathrm{dL})$ and low glucose $(55 \mathrm{mg} / \mathrm{dL}$, corresponding blood glucose: $136 \mathrm{mg} / \mathrm{dL}$ ). A thorough microbiological evaluation of the fluid did not contribute to the diagnosis. MRI of the brain revealed multiple ring-enhancing lesions (RELs) with perilesional oedema, scattered in both cerebral hemispheres, basal ganglia and cervicomedullary junction, with the largest lesion seen in left basal ganglia (figures $1 \mathrm{~A}$ and $2 \mathrm{~A}$ ).

Differentials of HIV-related central nervous system (CNS) lesions include progressive multifocal leucoencephalopathy (PML), lymphoma, and infection by toxoplasma, tuberculosis, cytomegalovirus, and herpes simplex virus which may be differentiated based on time course of presentation, CD4 counts, CSF analysis and neuroimaging. The presence of ring enhancing lesions, small size of lesions (1-2 cm usually, except a single large lesion (figure 2A)), involvement of grey and white matter, and contrast enhancement helped us narrow down the differential diagnosis to toxoplasmic encephalitis and tuberculosis. ${ }^{1}$

In toxoplasmosis, multiple RELs usually exist with oedema and mass effect with predilection for basal ganglia, and the frontal and parietal lobes; however, significant mass effect was not present in our case. ${ }^{2}$ Tuberculomas tend to involve the infratentorial compartment of brainstem and cerebellum, and involvement of the basal ganglia is usually due to vasculitic infarction instead of primary lesions. ${ }^{3}$ There is no reliable way to exclude CNS tuberculosis, especially in an endemic country like India where the prevalence of CNS tuberculosis is comparable with that of toxoplasmosis. ${ }^{4}$ Typically, patients with severe immune suppression (CD4 count $<200 / \mathrm{mm}^{3}$ ) are at risk of infection with

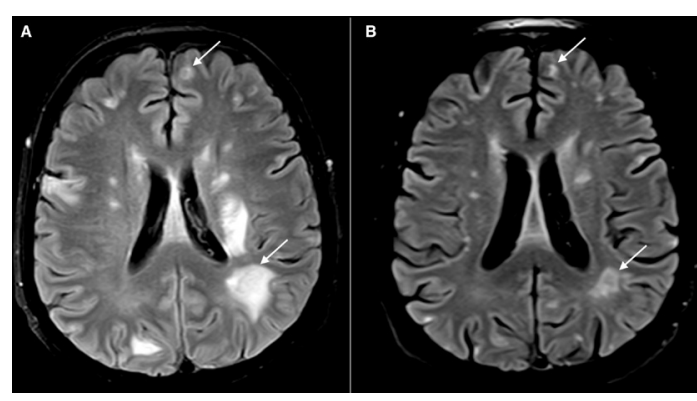

Figure 1 Axial T2 FLAIR MRI of the brain image showing hyperintense lesions in bilateral basal ganglia and subcortical white matter with significant perilesional oedema shown by arrows (A). Subsequent MRI sequence after 20 days of co-trimoxazole therapy for toxoplasmosis showed marked reduction in ring-enhancing lesions and decrease in oedema (B). FLAIR, fluid-attenuated inversion recovery.

toxoplasma, cryptococcus and cytomegalovirus, whereas patients with moderate immune suppression (CD4 counts $200-500$ cells $/ \mathrm{mm}^{3}$ ) are at risk of tuberculous meningitis and PML.

The patient was treated for both infections with co-trimoxazole, steroids and antitubercular therapy. He improved clinically and a repeat MRI at 2 weeks demonstrated near-resolution of the RELs and oedema (figures $1 \mathrm{~B}$ and $2 \mathrm{~B}$ ). The rapid response to toxoplasmosis therapy on imaging, ${ }^{5}$ prominent RELs in the basal ganglia, negative CSF Xpert MTB/RIF (test sensitivity of $71 \%$ ), ${ }^{6}$ and absence of basal exudates or enhancement,

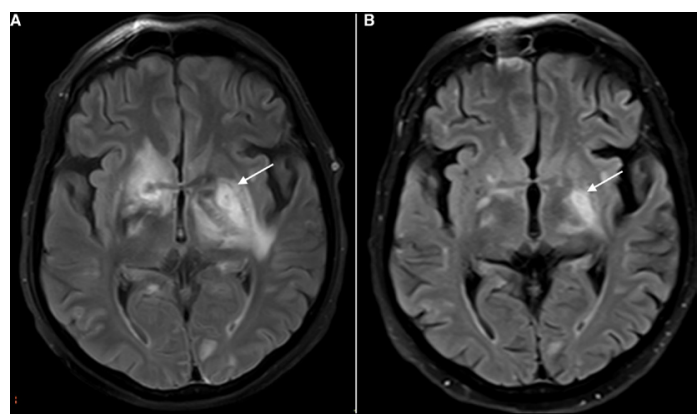

Figure 2 Axial T2 FLAIR MRI of the brain image showing multiple ring-enhancing hyperintense lesions in bilateral cerebral hemispheres and basal ganglia (arrows), largest lesion in left basal ganglia measuring $3.8 \times 1.6$ $\mathrm{cm}$ (A). Axial T2 FLAIR MRI of the brain after 20 days of treatment showing significant reduction in the number of lesions and perilesional oedema (B). FLAIR, fluidattenuated inversion recovery. 
hydrocephalus, and cranial neuropathies helped us tailor the therapy in this patient and antitubercular therapy was discontinued. He was started on ART after 4 weeks and was doing well on follow-up at 2 months.

\section{Learning points}

HIVIAIDS predisposes to several opportunistic infections of the central nervous system including tuberculosis, toxoplasmosis, cryptococcosis and progressive multifocal leucoencephalopathy.

- Many of them can present with ring-enhancing lesions on imaging and can be difficult to diagnose with certainty.

- Treatment for toxoplasmosis yields rapid resolution in imaging findings and repeat MRI of the brain performed at 2 weeks of therapy helped confirm our diagnosis and discontinue empirical antitubercular therapy.

Contributors The patient was clinically managed by MP, UA and PJ. The manuscript was drafted by MP. Both UA and MP edited the final manuscript, which was approved by PJ.
Funding The authors have not declared a specific grant for this research from any funding agency in the public, commercial or not-for-profit sectors.

Competing interests None declared.

Patient consent for publication Obtained.

Provenance and peer review Not commissioned; externally peer reviewed.

\section{ORCID iDs}

Umang Arora http://orcid.org/0000-0002-4366-0776

Pankaj Jorwal http://orcid.org/0000-0002-3722-4310

\section{REFERENCES}

1 Tan IL, Smith BR, von Geldern G, et al. Hiv-Associated opportunistic infections of the CNS. Lancet Neurol 2012;11:605-17.

2 Berger JR. Mass lesions of the brain in AIDS: the dilemmas of distinguishing toxoplasmosis from primary CNS lymphoma. AJNR Am J Neuroradiol 2003;24:554-5.

3 Sanei Taheri M, Karimi MA, Haghighatkhah H, et al. Central nervous system tuberculosis: an imaging-focused review of a reemerging disease. Radiol Res Pract 2015;2015:1-8.

4 Lanjewar DN, Jain PP, Shetty CR. Profile of central nervous system pathology in patients with AIDS: an autopsy study from India. AIDS 1998:12:309-13.

5 Nimir AR, Osman E, Ibrahim IAA, et al. Is it Toxoplasma encephalitis, HIV encephalopathy or brain tuberculoma? BMJ Case Rep 2013;2013. doi:10.1136/bcr2013-008803. [Epub ahead of print: 10 Apr 2013]

6 Kohli M, Schiller I, Dendukuri N, et al. Xpert MTB/RIF ultra and Xpert MTB/RIF assays for extrapulmonary tuberculosis and rifampicin resistance in adults. Cochrane Database Syst Rev 2021;1:CD012768.

Copyright 2021 BMJ Publishing Group. All rights reserved. For permission to reuse any of this content visit https://www.bmj.com/company/products-services/rights-and-licensing/permissions/

BMJ Case Report Fellows may re-use this article for personal use and teaching without any further permission.

Become a Fellow of BMJ Case Reports today and you can:

- Submit as many cases as you like

Enjoy fast sympathetic peer review and rapid publication of accepted articles

Access all the published articles

Re-use any of the published material for personal use and teaching without further permission

Customer Service

If you have any further queries about your subscription, please contact our customer services team on +44 (0) 2071111105 or via email at support@bmj.com.

Visit casereports.bmj.com for more articles like this and to become a Fellow 